\title{
A Critique of Contribution of Tourism to Jobs in Southern African Development Community (SADC): Implications for Post COVID-19 Pandemic
}

\author{
Shepherd Nyaruwata ${ }^{1 *}$ \\ Miriam Mbasera ${ }^{2}$ \\ University of Zimbabwe (UZ), Zimbabwe $e^{1,2}$
}

\begin{abstract}
The outbreak of the COVID-19 pandemic in Wuhan province in China in December 2019 and its subsequent spread throughout the world brought the tourism industry to a standstill. Businesses closed down and large numbers of workers including those in the tourism industry lost their jobs. The Southern African Development Community (SADC) experienced similar challenges that occurred at the global level. The aim of the study was to investigate the impact that COVID-19 had on jobs in the tourism industry in the SADC region. The study employed a desk research approach. The study showed that the impact of COVID-19 on the tourism sector has set back the gains that the region had accumulated over the twenty three years of working together as one destination since the formation of the Regional Tourism Organization of Southern Africa (RETOSA) in 1997. A number of governments in the region responded by implementing measures that were aimed at cushioning tourism enterprises from the impact of the pandemic. All the subsectors of the tourism industry had to undertake a range of cost cutting measure to mitigate the impact of the pandemic the majority of which negatively affected employees in the sector. The study recommends that the public and private sector in the region closely work together to develop and implement policies and strategies that will create traveller confidence on the destination with regard to health and safety issues. It is further recommended that the governments of the region continue to assist business enterprises to enable them to be effective partners in the post COVID-19 programmes that each country will roll out.
\end{abstract}

Keywords: COVID-19, Tourism, SADC, Jobs, Enterprises, Africa

Corresponding author: Shepherd Nyaruwata; E-mail: scnyaruwata@gmail.com DOI: https://doi.org/10.37227/ITHJ-2021-03-116

\section{Introduction}

The onset of the Covid-19 pandemic on the global scene towards the end of 2019 led to the stand still of the tourism industry. Coronavirus (COVID -19) is a global health pandemic that has triggered an unprecedented crisis in the tourism industry globally (Gossling, Scot\& Hall, 2020). Governments across the world have had to implement necessary measures to contain the spread of the coronavirus such that the capacities of the health system were not overwhelmed by the rate of transmission. A direct impact of this was a restriction on 
movement people globally through internal lockdowns and closure of international borders (UNWTO, 2020; Horaira, 2021). Over a short space of time in 2020 international tourism came to a standstill. Tourism facilities became empty and companies had to implement survival strategies the majority of which negatively affected employees in the sector. The SADC region was not spared from the ravages of the COVID -19 pandemic and both the governments and the private sector in the region had to implement a range of mitigatory policies and strategies which were aimed at reducing the overall impact of the pandemic on the tourism sector.

Tourism is one of the world's major economic sectors. It is the third-largest export category (after fuels and chemicals) and in 2019 accounted for $7 \%$ of global trade representing over $20 \%$ of the global GDP. In 2019 a total of 1.460 million international tourist arrivals were recorded which was a 4\% growth over the 2018 figure. The sector accounted for 1.481 billion US dollars in revenue (UNWTO, 2020; Horaira, 2021). Being a labour intensive industry due its need for personal contact it accounted for 330 million direct jobs globally in 2019. The figure accounted for $10.3 \%$ of global employment (ILO, 2020:1). According to the UNWTO for every 11jobs in the world, one is found in the tourism sector (UNWTO, 2019). Tourism therefore provided millions of jobs in both developing and developed economies. The majority of the workforce in the sector is made up of young people and women, with women comprising of $54 \%$ of the employees of the sector worldwide (ILO, 2020)

The COVID-19 pandemic has cut international tourist arrivals to unprecedented levels with 2020 recording a decline of $-73 \%$ over the 2019 figure and arrivals to Africa experiencing a decline of $-74 \%$ during the same period ( UNWTO , 2021). Data from UNWTO indicates that 2021 has not yet experienced any reserve of the situation that obtained in 2020 in terms of tourists arrivals and other indicators from the sector as the period January to March 2021 experienced a decline of $-83 \%$ in arrivals compared to the same period in 2020 (UNWTO Barometer, May, 2021) This is due to a number of factors, for instance by February 2021, 32\% of global destinations were still completely closed to international tourists (ibid). According to UNWTO (2019) $80 \%$ of the enterprises in the tourism industry are made up of micro, small and medium size enterprises (MSMEs) and hence the onset of the COVID-19 pandemic put an estimated 120 million jobs at risk (ILO, 2020) Figure 1 shows UNWTO's tourist arrivals in 2020 and scenarios for 2021.

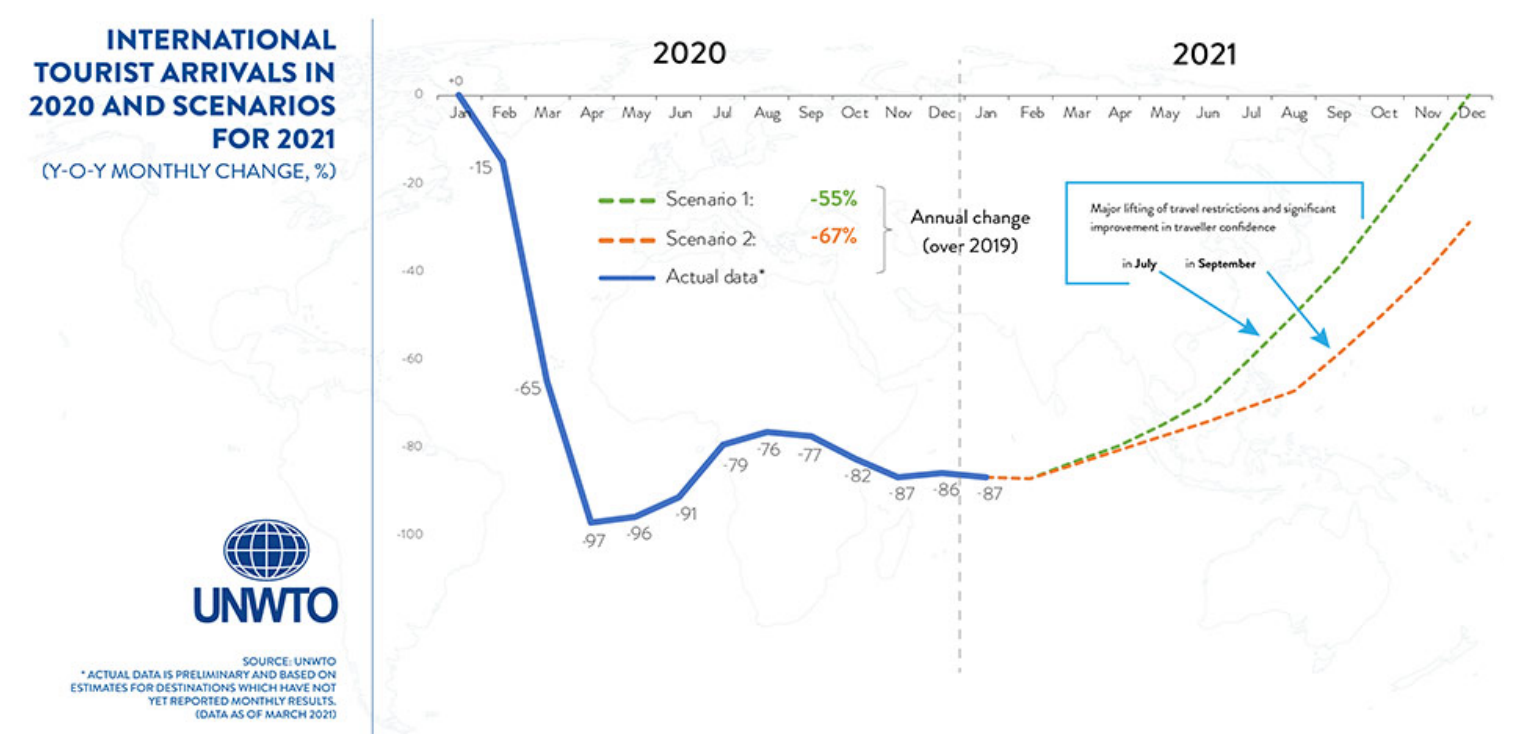


Figure 1: International tourist arrivals in 2020 and scenarios for 2021: Source; UNWTO, (2021)

The development has put at risk at least 120 million jobs at risks (WTTC, 2021). The scenarios painted by the WTTC show grim picture for the future of jobs in the industry with the best case scenario predicting a global loss of 98.2 million jobs, a baseline scenario indicating a loss of 121.1 million jobs and the worst case scenario indicating a total of 175.5 million jobs (ibid:4).

At the beginning of 2020, Africa's tourism sector looked set for a lucrative year having recorded a growth of $2 \%$ in 2019 0ver the previous year. But when COVID-19 struck, tourists stopped coming and the industry ground to a sudden halt resulting in a decline of $-74 \%$ in 2020 compared to 2019 (UNWTO, 2021. Overnight, hotel bookings were cancelled, safaris postponed and cultural tours abandoned. The negative trend continued in the first quarter of 2021 with the continent recording a decline of $-81 \%$ for period January to March 2021 compared to the same period in 2020 (ibid:2)

Tourism across the continent has always relied on international travelers. But now, a dangerous combination of national lockdowns, a tiny local tourism customer base, and an industry aimed at high-paying foreign visitors means Africa's tourism industry may not adapt quickly enough to avoid collapse. The overall impact of the development on jobs and livelihoods in the continent has been catastrophic (Page, 2021)

The countries of the Southern African Development Community (SADC) region are among those hardest hit by the economic impacts of COVID-19. The onset of the COVID-19 pandemic exacerbated the economic challenges of a number of countries whose economies were already experiencing substantial difficulties of their own making, for instance Zimbabwe , Lesotho and Mozambique. The severely-hit countries are those with highly-developed tourism and services sectors, which include Seychelles, Botswana, Mauritius and the Comoros (World Bank, 2020). Figure 2 shows the SADC member states.

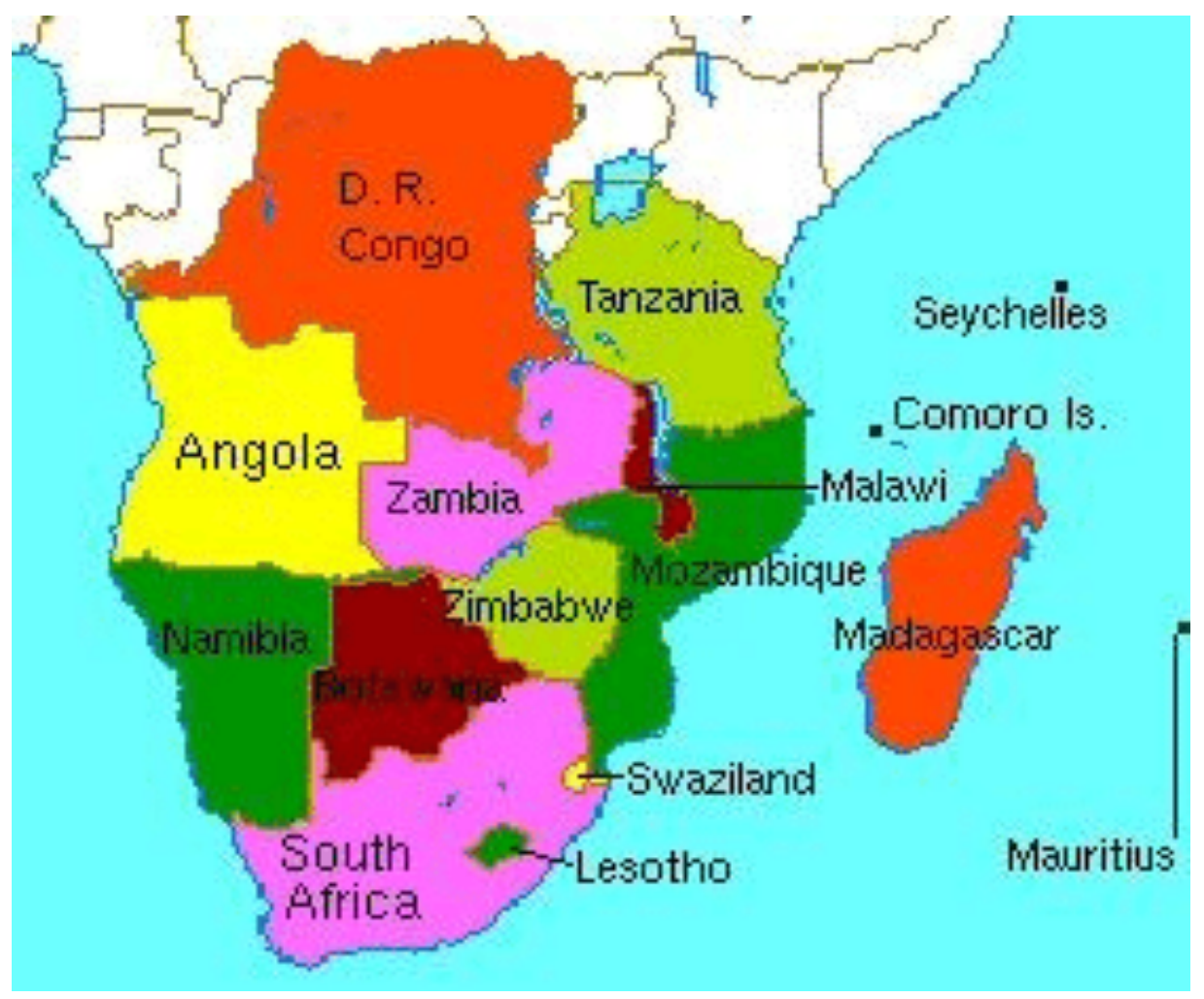


Figure 2: SADC member states; Source: Google maps.

\section{Problem of the Study}

The COVID-19 pandemic has been different from other coronavirus epidemics of this and previous century in its evolution, severity and complexity with regard to its spread. Initial responses from governments were driven by national interests which focused on the health and safety needs of each country. The responses to the pandemic involved a cocktail of policies and strategies which included among others: national lockdowns that prohibited intercity/interprovincial travel, confinements to residential areas, closure of international borders, banning of domestic and international flights, closure of businesses including those in the tourism industry, national testing for the pandemic, vaccination programmes and implementation of quarantine strategies.

The World Health Organization (WHO) declared the outbreak of the disease as a Public Health Emergency of International Concern on 30th January 2020 and as a Pandemic on 11th March 2020 (WHO, 2020). On the day the disease was declared a pandemic there only then a total of 118000 people affected by the pandemic in 114 countries (ibid).However as of 13th of June 2021 the number of confirmed cases stood at 175306598 with a total of 3792 777 having succumbed to the pandemic worldwide (WHO, 2021). These developments have scared potential travellers to venture out for domestic travel and worse still for international travel even in situations where restrictions on travel were being relaxed. Countries have had to deal with second waves of the pandemic and there is currently evidence of third wave of the pandemic occurring in some countries. The situation has further been compounded by the discovery of different variants of the virus which are resistant to available vaccines. Finally availability and distributions of vaccines have been skewed in favour of developed countries which have the financial resources to purchase them leaving the majority of the developing countries in a limbo with regard to instituting vaccination programmes for their own national.

The net results for tourism industry have been wholesale closure of businesses, furloughing of employees, cutting down on the number of employees through dismissals, early retirement, and part time employment. For rural communities who were depended on tourism for their livelihoods the development spelt disaster as their ability to absorb the shocks brought in by the pandemic was very minimal. Some have therefore turned to negative practices like wildlife poaching to sustain themselves. There are therefore a number of issues that need to be addressed in order to restart the tourism sector globally and there restore jobs and improve the livelihoods of those that depend on the sector. These cover the following areas: (ILO, 2020; UNWTO, 2020)

- Managing the crisis and mitigating the impact of the impact on the sector;

- Providing stimulus for accelerated recovery for the industry;

- Protecting livelihoods, jobs and enterprises;

- Strengthening partnerships between governments and the private sector;

- Building customer confidence through implementing robust safety and hygiene Programmes throughout the tourism value chain and

- adopting and implementing coordinated Covid-19 protocols globally.

The World Travel and Tourism presented at the G20 meeting (WTTC, 2021) a set of guidelines for both the public and private sector stakeholders in the tourism sector which if implemented will help restart the sector. Guidelines to the private sector included the following: (:2-3)

Guidelines to the public sector for the private sector: 
- Implement standardized global health and safety protocols across all geographies to facilitate a consistent and safe travel experience ;

- Cooperate with governments in their efforts on COVID-19 testing before departure and contact tracing tools within the international testing protocol and framework

- Develop and adopt innovative digital technologies that enable seamless travel, better manage visitor flows and improve traveler experience while making it safer;

- Offer flexibility for bookings.

Guidelines for governments:

- International coordination among governments to re-establish effective operations and resume international travel;

- Consider the implementation of international "air corridors";

- Align health and hygiene protocols and standardize measures;

- Continue to support the most affected by COVID-19 within the travel and tourism sector.

It important to note that some of the recommendations directed at both the private and public sector holders are being implemented in both the developed and developing countries.

\section{Objectives of the study}

The overall objective of the study was to assess the impact of COVID-19 on jobs and livelihoods in the tourism sector in the SADC region.

The specific objectives of the study were:

- To investigate the level of disruption by COVID-19 to the tourism sector in the SADC region;

- To determine the quantum of jobs lost due to the COVID-19 pandemic;

- To assess the impact of COVID-19 pandemic on the livelihoods of tourism employees and rural communities that participated in the sector;

- To examine the public and private tourism stakeholders the responses to the pandemic; and to make recommendations to guide the sustainable restart of the sector in the region

\section{Literature Review}

The importance of the tourism sector on economic development and social wellbeing has been recognised in both the developed and developing countries (Giap, Golap \& Ye 2016; Noori \& Zand 2013; Felleiro 2015). It has been argued that since tourism is labour intensive it enables employment creation and hence improves the wellbeing of rural populations (Motsatsi 2018). Tourism components such as hotels, restaurants, airlines, museums, entertainment, recreation, tour operators and travel agents offer services and products which translate into employment creation. The same thing would apply to industries which provide support services to tourism sector such as telecommunication networks, water and electricity supply. Economic and employment benefits of tourism would spill over to sectors such as agriculture, finance, health, transport and construction, a result of the broad supply chain linkages of the sector. Available evidence indicate that tourism sector contributes more to economic development and employment creation in countries with higher investment in tourism than those with less investment (Motsatsi, 2018) 
A number of studies carried out before the onset of the COVID-19 pandemic had shown a steady growth of direct, indirect and induced jobs in the tourism sector in the SADC region (WTTC, 2019; Motsatsi, 2018). For example whilst the sector accounted for 4.6 million direct jobs in 2011 these grew to 4.8 million in 2012 and stood at 6.8 million in 2018 (Makochekanwa, 2013; WTTC, 2019). The growth of tourism jobs were directly linked to the growth tourist arrivals to the region, for example tourist arrivals have increased from 21 million in 2009 to 26 million in 2018. Jobs in the travel and tourism sector had also increased from 4.6 million in 2011 to 6.8 million in 2018. Table 1 below shows the growth of tourism jobs in selected SADC member states.

Table 1 Growth of tourism jobs in selected SADC member states2000-2018

\begin{tabular}{|l|l|l|l|l|}
\hline Country & & & & \\
\hline & $\mathbf{2 0 0 0}$ & $\mathbf{2 0 0 5}$ & $\mathbf{2 0 1 0}$ & $\mathbf{2 0 1 8}$ \\
\hline Mauritius & 30000 & 35000 & 42000 & 127000 \\
\hline South Africa & 992000 & 1222000 & 1243000 & 1500000 \\
\hline Namibia & 43000 & 63000 & 108000 & 122000 \\
\hline Tanzania & 546000 & 1045000 & 1143000 & 1400000 \\
\hline Zambia & 43000 & 61000 & 60000 & 318000 \\
\hline
\end{tabular}

Source: Makochekanwa, (2013); WTTC, (2019)

The major growth areas for job creation in the SADC region had been in the accommodation and conference and exhibition areas. All the countries in the region had witnessed substantial investment in the accommodation subsector at both ends of the market. International investors had concentrated on the high end of the market with four to three stars being opened in countries like South Africa, Mozambique, Mauritius and Tanzania whilst a large number of local investors had concentrated on investing in one three star properties (Roger, 2014). Further the region had also witnessed an explosion of family owned bed and breakfast properties which have become a feature of alternative accommodation for visitors to countries like South Africa, Lesotho, Zimbabwe and Eswatini. This development had been augmented by the spread of the Airbnb global model which had now been established in the majority of SADC countries (Rogerson, 2014, Price Waterhouse Coopers, 2018 ). All these developments had created demand for workers with different skills within the member states. The development had also led to intensified intra SADC migration of both professional and nonprofessional tourism workers (International Office of Migration, 2016).

The contribution of the tourism industry to job creation differed from country to country within the SADC region depending on the level of economic diversification and the prioritization that the sector has been given. Figure 3 below shows the average percent contribution of tourism to employment for the SADC member states for the period 19972015. 


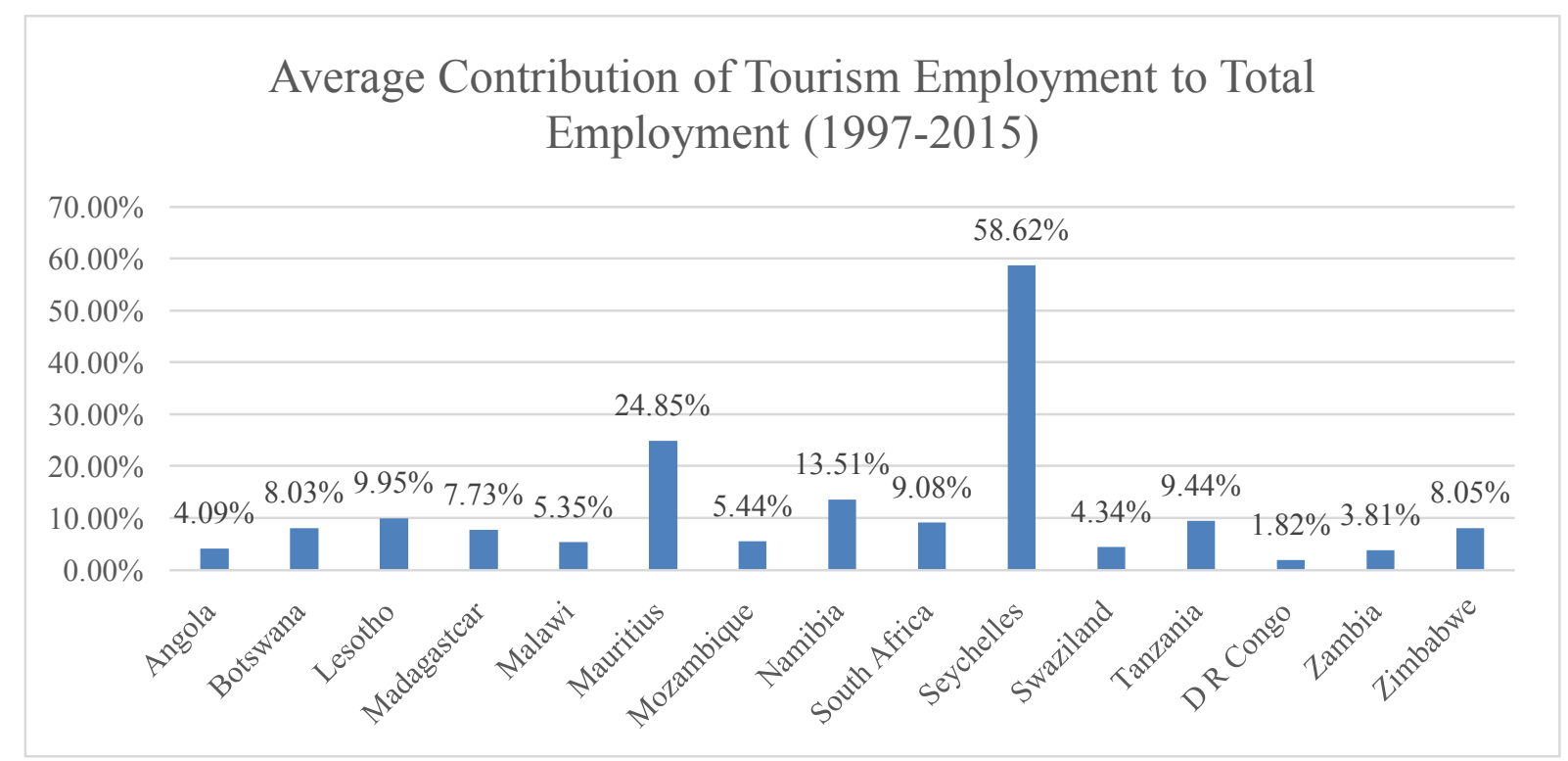

Figure 3: Contribution of tourism employment to total employment in SADC: Source: Motsatsi 2018.

On average, tourism employment accounted for 58. 6\% of total employment in Seychelles, 24. 9\% in Mauritius and $13.5 \%$ in Namibia during the period 1997-2015.

The nature and characteristics of tourism jobs in the SADC reflect those that are found at the global level. The key characteristics include the following: (Vargas\& Aguir, 2004; Fergus, 2009)

$>$ Dominance of menial activities-dishwashing, concierge, landscaping, rooms cleaning etc.;

$>$ Horizontal and vertical gender discrimination;

$>$ Unsocial and long working hours;

$>$ Prevalence of low wages and salaries;

$>$ Prevalence of seasonal and part time work;

$>$ Exposure to health risks; and

$>$ Poor regulatory environment.

The majority of tourism jobs at lower levels are not inspiring and hence this results in high staff turnover. This is evident in most hotels in SADC countries where low level workers like receptionists and waiters use the tourism jobs as stopgap measures whilst they are looking for other lucrative employment (Tsangu, 2016). This problem is also common with new graduates in tourism and hospitality who migrate to other sectors after a shot stay within tourism. For example a study carried by Tsangu (2018) in the Western Cape Province in South Africa indicated that tourism graduate lasted an average of three years before they migrated to other sectors of the South African economy due to a number of perceived challenges which include low pay and limited opportunities of career advancement.

Evidence from a number of studies undertaken in the region (Nyaruwata and Nyaruwata, 2013, SADC, 2001) show strong gender discrimination in managerial position in both the private and public sector. This is a major concern as women occupy the bulk of low and middle management positions within the industry. Horizontally women are employed as waitresses, chambermaids, cleaners, travel agencies sales persons, tour 
operators' sales persons, receptionists' and flight attendants whereas men are employed as gardeners, barmen, chefs, drivers, pilots, construction workers and hunters. Vertically women are concentrated in the lower levels of occupations with very few being able to break the "glass ceiling" giving rise to a typical gender pyramid (Vargas and Aguir 2004). The vertical description of women in the sector means is therefore a disincentive for attracting and retaining high calibre female cadres to the tourism industry in the SADC region.

Figure 4 below shows the composition of SADC CEOs in the study that was carried out in 2013. Anecdotal evidence show that the situation has not changed meaningfully up to the present.

Figure 4: Gender composition of tourism Ceos in SADC in 2013

\section{Chief Executive officer}

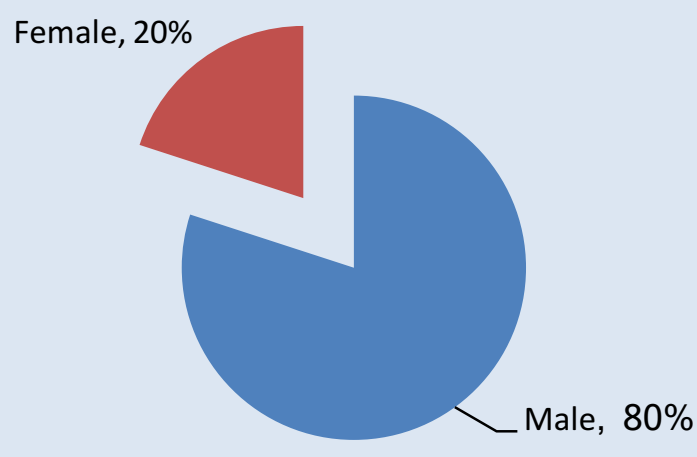

Source: Nyaruwata, S. \& Nyaruwata, L.:2013

The results were a total contradiction of the policy frameworks that have been adopted by member states. SADC governments are signatories to various regional and international conventions, treaties, declarations and protocols that seek to promote and create an enabling environment for the attainment of gender equity and women's attainment of positions of decision making in all areas of the SADC economy. These include, the Convention on the Elimination of All forms of Violence Against Women (CEDAW) (1991), the Convention on Civil and Political Rights (CCPR); the Global Platform for Action and the Beijing Declaration (1995). In 1997 these countries signed the SADC Declaration on Gender and Development as well as its addendum on the Prevention and Eradication of Violence against Women and Children (Nyaruwata \&Nyaruwata, 2013, SADC 2018). Table 2 below shows the position of women in different job level in Zimbabwean tourism industry. 
Table 2 Gender composition of employees in Zimbabwe's three major hotel groups in 2011.

\begin{tabular}{|l|l|l|l|}
\hline Level & \#of Females & \#of Males & \%of Women \\
\hline Directors and CEOs & 4 & 7 & $\mathbf{3 6 . 4}$ \\
\hline General Managers & 5 & 21 & $\mathbf{1 9 . 2}$ \\
\hline Senior Managers & 76 & 119 & $\mathbf{3 9 . 9}$ \\
\hline Front Office Managers & 78 & 143 & $\mathbf{3 5 . 3}$ \\
\hline General Workers & 1225 & 1829 & $\mathbf{4 0 . 1}$ \\
\hline Totals & 1388 & 2119 & $\mathbf{3 6 . 9}$ \\
\hline
\end{tabular}

Source: Government of Zimbabwe: Ministry of Women's Affairs, Gender and Community Development (2011)

The situation that obtained in Zimbabwe was reflective of similar situations in other SADC member states. Indications are that nothing much has changed to date.

The onset of the COVID-19 pandemic on the global stage disrupted all the trends that had become normal within the tourism industry. The changes are clearly captured by Gossling et al; (2020) who traces the developments that occurred in the sector during the early months of the pandemic in 2020. They noted that by March 2020 most accommodation had already experienced $-50 \%$ decline in occupancy rates with hotels in places like Kenya registering $-70 \%$ decline in occupancy rates (ibid:2). This was due to a combination of factors which included cancellations, lockdowns, travel advisories and border closures. They further noted that the narrative on the tourism sector changed over a very short period of time from that of over-tourism to one of no-tourism (Gossling et al, 2020:6)

There is general consensus in the literature that no country has escaped the catastrophic impact of COVID-19 on its tourism industry (UNWTO, 2020; UNDP, 2020; Dube, 2020 \& World Bank, 2021) The pandemic has similarly affected the tourism sectors of top tourism destinations like Spain and France and small islands developing states (SDIS) like Fiji, Seychelles and Trinidad and Tobago (UNDP, 2020:2)

The United Nations World Tourism Organizations carried out a study (UNWTO, 2020) on the impacts of COVID-19 on the sector and came up with guidelines on how member states should deal with the challenge with a view of arresting the decline of the industry, save jobs and restart the recovery of sector. The guidelines focused on three main areas:(ibid: 7 )

- managing the crisis and mitigating the impact of COVID-19;

- providing stimulus for accelerated recovery; and

- preparing for tomorrow

The 23 broad recommendations included the following (UNWTO, 2020: 12-14)

- incentivising job retentions, sustain the self-employed and protect the most vulnerable groups

- $\quad$ support companies' liquidity;

- review taxes, charges, levies and regulations impacting on tourism and transport;

- ensure consumer protection and confidence

- provide financial stimulus for tourism investment and operations

- advance travel facilitation;

- promote new jobs and invest in human capital and talent development;

- invest in partnerships; 
- diversify markets, products and services; and

- prepare for crisis, build resilience and ensure tourism is part of the national emergency mechanism and systems.

The recommendations from UNWTO have formed the basis for the responses to the COVID-19 of main countries including those within the SADC region as will be discussed fully in the findings of the study.

The United Nations Development Programme (UNDP) highlighted in its policy brief (UNDP, 2020) how the pandemic had affected global economies, livelihoods, public services and investment opportunities globally. It noted that with regard to the tourism sector the pandemic had affected the march towards achievements of Sustainable Development Goals (SDGs) 1 and 10. Similar observations were made by the ILO report (2020) which argued that achieving of the SDGs 10,12, 13, 14 and 15 were going to be a challenge as a result of the impact of the COVID -19 on the tourism industry(ibid:1)

\section{Research Methodology}

This study employed a desk research approach. A desk research is a review of information available including documents and historic data (McCaston, 2005). The researchers accessed published information on tourism and jobs through the internet. The data included that which is available in scholarly journals, in international organizations annual reports, in periodic reports of regional organizations like SADC and in SADC member states' monthly and annual reports. Annual reports from international organizations like the United Nations World Tourism Organization (UNWTO), International Labour Organization (ILO) and the World Travel and Tourism Council (WTTC) were extensively consulted.

The major advantages of desk research approach are the cost effectiveness and convenience it provides as someone else has already collected the data. The researcher therefore does not have to devote financial resources to data collection (Smith, 2008). This is helpful when researchers are not able to access adequate funding for the project as was the case in the current study. However it is important to point out that use of secondary data has a number of challenges which researchers have to take cognisance of when using this approach. The challenges include issues of validity and reliability of the data, time lag and the need to observe proprietary issues.

\section{Results and Analysis}

The impact of COVID-19 on the tourism sector has set back the gains that the region had accumulated over the twenty three years of working together since the formation of the Regional Tourism Organization of Southern Africa (RETOSA) in 1997. Border closures, national lockdowns, quarantine programmes, demands for PRC testing for visitors, bans of entry into member states of visitors from COVID-19 "hotspot" countries and high rates of COVID-19 infections in a number of member states in the region all contributed to the decline and almost total standstill of the tourism industry in the region. The impact of the pandemic has been different to that of other health scares to travel to the SADC region. For instance the outbreak of Ebola disease in West Africa in 2014 led to the closure of national borders of countries of that region only (Mapanga \& Henama (2019). The impact in the SADC region of Ebola was a noticeable decline to tourist arrivals in 2015 as a result of health risk perception by international travellers who viewed Africa as one destination (WTTC, 2018). 
The closure of borders and implementation of national lockdowns brought a bloodbath to the tourism industry in the region. Businesses responded by retrenching workers, cutting salaries and wages, sending staff on long unpaid leave, giving incentives for voluntary retirement and employing staff on a temporary basis (Dube, 2021; UNDP, 2020; Africa Sun, 2021).

Within each members state the small enterprises involved in accommodation, tour operations, travel agents and food and beverages activities were the first to fail to with withstand the shocks brought about by the pandemic (Ragoobur , 202) However as bans on international and internal travel continued to be implemented big organizations in the industry were unable to stand the strains brought about the impacts of the pandemic and had to implement a range of cost containment measures. For instance the largest airline in the region, South African Airways stopped flying in March 2020 and went into judicial management in order to protect its assets (Dube, 2021). Employees were furloughed, dismissed or offered incentives for voluntary retirement. Similarly Comair reduced its workforce from 2200 to 1800 through voluntary retrenchments and early retirement (ibid: 10). In Zimbabwe the biggest hotel chain, African Sun dismissed 300 of its 900 work force and extended furloughs of essential staff at the end of the 2020 financial year (Africa Sun, 2021:25).

At the regional level member states agreed as early as March 2020 to implement a number of the guidelines that had been developed and championed by the World Health Organization (SADC, 2020). For example by April 2020 most SADC countries had declared states of emergency and were putting in place measures that were aimed at stopping the spread of the virus internally. These measures included among other things partial and full lockdowns, closure of national borders, rolling out education awareness programmes, assessing of the capacities of national health facilities and allocating additional resources to the national referral hospitals provincial and district hospitals (SADC, 2020).

Each country implemented a set of policies and strategies to protect the tourism industry which were guided by its prioritization of the sector, its capacity to meet the competing demands of other sectors and the nature of its relationship with international cooperating partners. Table 3 below summarizes in broad terms the policies and measures adopted by the SADC member state in response to the impact of COVID-19 on the tourism industry.

Table 3: Policies and Measures adopted by SADC members states

\begin{tabular}{|l|l|l|}
\hline & Policies/Measures & Examples from Member States \\
\hline 1 & $\begin{array}{l}\text { Declaration of national } \\
\text { state of emergency }\end{array}$ & All members states between March \&April 2020 \\
\hline 2 & $\begin{array}{l}\text { Implementation of } \\
\text { national lockdowns }\end{array}$ & All members states at different periods since March 2020 \\
\hline 3 & $\begin{array}{l}\text { Closure of national } \\
\text { borders and national } \\
\text { airspace }\end{array}$ & All member states at different periods since March 2020 \\
\hline 4 & $\begin{array}{l}\text { Tourism recovery } \\
\text { strategies }\end{array}$ & $\begin{array}{l}\text { Most member states have crafted some recovery plan and } \\
\text { are currently implementing the domestic tourism } \\
\text { components of the plans for example South Africa, } \\
\text { Zimbabwe, Zambia Namibia and Mauritious. }\end{array}$ \\
\hline 5 & Cash grants/subsidies & \multicolumn{1}{|c|}{ South African enterprises availed grants for } \\
\hline
\end{tabular}




\begin{tabular}{|c|c|c|}
\hline & for employees & $\begin{array}{l}\text { employee wages for three month(March-May 2020) } \\
\text { - Mauritian enterprises operators were availed } \\
\text { subsidies for period in } 2020 \text { (Wage Assistance } \\
\text { Scheme and Self Employment Assistance Scheme } \\
\text { with a total disbursement of US } \$ 265 \text { million in } \\
2020 \text { ) } \\
\text { - Companies in Seychelles accessed grants for the } \\
\text { period March to December } 2020 \\
\text { - In Botswana government under the COVID-19 relief } \\
\text { fund offered companies 50\% of employees wage } \\
\text { bill } \\
\text { Different forms of grants and subsidies availed to } \\
\text { companies in , Lesotho, Namibia, Tanzania and } \\
\text { Zambia }\end{array}$ \\
\hline 6 & Tax & $\begin{array}{l}\text { Availed by governments in all member states with the } \\
\text { specificities being different in each country }\end{array}$ \\
\hline 7 & Liqu & $\begin{array}{l}\text { Governments of Seychelles, Mauritius and South Africa } \\
\text { offered enterprises funds at concessionary interest rate(eg } \\
1.5 \% \text { interest rate for the Seychelles funds and R1.6 billion } \\
\text { fund provided by the South African government). }\end{array}$ \\
\hline 8 & $\begin{array}{l}\text { Loan } \\
\text { schemes }\end{array}$ & Availed in most of the member states \\
\hline 9 & $\begin{array}{l}\text { Training and up- } \\
\text { skilling incentives for } \\
\text { the industry }\end{array}$ & $\begin{array}{l}\text { Availed in South Africa, Botswana, Namibia, Mauritius, } \\
\text { Seychelles and Zambia }\end{array}$ \\
\hline 10 & $\begin{array}{l}\text { Cash payments to laid } \\
\text { off staff }\end{array}$ & $\begin{array}{l}\text { Government of Seychelles paid laid off staff a percentage of } \\
\text { their monthly wages and assisted in their placement in other } \\
\text { enterprises and their skills upgrading. }\end{array}$ \\
\hline 11 & $\begin{array}{l}\text { Loan repayment } \\
\text { moratorium }\end{array}$ & $\begin{array}{l}\text { The facility was offered in countries like Mauritius, } \\
\text { Botswana, Namibia and Seychelles. }\end{array}$ \\
\hline 12 & Rental relief & $\begin{array}{l}\text { Companies that operated from government owned } \\
\text { properties or leased land from local authorities and } \\
\text { government departments were given a sabbatical on rent } \\
\text { payments in a number of countries, for example in } \\
\text { Mauritius and Botswana. }\end{array}$ \\
\hline
\end{tabular}

The SADC member states have been implementing a wide variety of Community Based Natural Resources Management (CBNRM) programmes for a long time. CBNRM originated in Zimbabwe as the Communal Area Management Programme For Indigenous Resources (CAMPFIRE) and aims to provide incentives for the local population to conserve natural resources in their immediate surroundings by providing them exclusive resource user rights and associated benefits. In other words, CBNRM seeks to improve natural resource conservation, improve rural livelihoods and reduce human wildlife conflicts as well as poverty. Most early CBNRM projects focused on wildlife utilisation (hunting and tourism), but later on CBNRM extended to other natural resources. The approach has been adopted in the majority of countries (Botswana, Lesotho, Eswatini, Mozambique Namibia, South Africa, Tanzania and Zambia with different levels of success (Mkono, 2019). 
The impact of COVID-19 on the communities involved in these programmes throughout the region has been devastating. Given that these communities have minimal ability to mitigate against the sudden loss of their additional incomes from tourism a most of them are now driving their livelihoods from unsustainable farming activities have constantly been under threat of climatic change and wildlife. Lendeloo, Pinto, and Sullivan, (2020) pointed out that the communities lost revenue and cash flow which was key to effective management of their tourism enterprises. They further noted that the loss of employment opportunities negatively affected their livelihoods. The study finally argued that the withdrawal of donor funded experts from the conservancies due to lockdowns will derail the re-start of the community enterprises due to lack of technical capacities within the rural communities.(ibid, $p$

The overall result in the areas were the CBNRM programmes are being practiced has been an increase in human wildlife conflict with officials that are mandated to look after these areas being unable to offer the needed leadership due to the budgetary and other challenges that they are also encountering due to the national impacts of COVID-19 on each country's fiscal space.

The COVID-19 pandemic is showing no signs of coming to an end in both the developed and developing countries. Some countries in the SADC region are experiencing a third wave of the pandemic in 2021 (South Africa and Zimbabwe) and therefore the prospects of recovery and a restart of the tourism is still a long way. The situation does not augur well for the MSMEs as well as some of the large enterprises in the sector. A large number of both the medium sized and large companies in the industry were heavily borrowed and hence their ability to restart operations when the pandemic subsides is doubtful. Perhaps the case of South African Airways gives a pointer to the pathways that companies in the industry in the region will follow. The South African government recently (May 2021) sold 51\% of its shareholding to a local consortium that has enabled the airline to access the necessary capital to restart its operations.

\section{Conclusions}

The COVID-19 pandemic has destroyed jobs in both the developed and developing countries with the SADC region witnessing massive layoffs of workers in the tourism industry. Governments in the region have concentrated on activities that were geared at protection of the citizens from the ravages of the pandemic. The programmes and strategies that have been put in place to help businesses including tourism enterprises to navigate the challenges brought about by the pandemic have been at best short term and worst mere tokenism. For the tourism businesses to restart effectively they will need substantial assistance from financial institutions as well as the governments of the member states of the region. Evidence from the research shows that some of the enterprises both small and large will vanish from the scene. Conservation of the natural resources of the region on which most of tourism of the region is based is at risk.

National parks authorities who are responsible for the management of these resources are hamstrung by lack of resources in terms personnel, equipment and budgetary allocations. They are therefore unable to effectively carry out their mandates. Given the increased human -wildlife conflict that has now been exacerbated by the onset on the pandemic the future of biodiversity conservation in the SADC region is doubtful unless robust programmes are put by both governments and its cooperating partners which address the needs of the national parks authorities and those of the communities that live adjacent to the various protected areas of the member states. In order for an effective re- 
start of the tourism industry to take place the public and private sector stakeholders need to work together and operationalize programmes that will build traveller confidence with regard to health and safety issues in the destination. This is the only way the region will be able to save tourism jobs and create new ones.

\section{Recommendations}

In order for the SADC region to effectively recover and re-start the tourism industry there are a number of strategies that both the governments of the region and the private sector need to operationalize.

The governments of the regions need to effective coordinate the implementation of programmes that aimed assuring traveller of matters of safety, hygiene, testing, and procedures. Equally, governments will need to take steps to ensure that destination communities are motivated to take their COVID-19 jabs so that the customers are assured that they are being served by people that have minimal chances of being infected by the virus. Purchasing of the necessary vaccines and implementation of the national vaccination programmes are therefore a major priority for the governments of the region

The governments need to continue to offer the cash subsidies and grants to the sector to enable the industry to offer employees some reasonable social safety nets and to give the sector the ability to retain key staff members who will be critical for the industry during its rebound and recovery period.

National tourism authorities in the region need to intensify the promotion of domestic tourism programmes which the majority of them have commenced. This will help to create some demand for the tourism businesses in each country. The movement of domestic tourist to various attractions in different countries will also help create confidence in the international travellers as this will be an indication that the destinations are safe.

Government of the region need to roll out subsector specific training programmes aimed at the employees in the industry. This will help to upgrade the skills of the worker and prepare them for restart of the industry.

It is essential that the governments of the region create and offer adequate social safety nets to the communities that live adjacent to the protected areas which will help to improve their livelihoods. Hand in hand with this the governments need to adequately resource national parks authorities so as to enable them to carry out their mandates effectively.

Banks within the region need to in place a menu of facilities which are aimed at ensuring survival of the tourism businesses, which should include among others: freezing of loan repayments and wavering of interests on bank overdrafts.

\section{References}

Acheampong, K. \& Tseane-Gumbi, L. (2016). Tourism in the SADC region and challenges facing the youth market: the Mozambican experience. African Journal of Hospitality, Tourism and Leisure 5(4): 1-16.

African Sun (2021).Audited Condensed Financial Statements for the Year Ended December 2020. available at: file:///C:/Users/User1/Downloads/african-sunlimited-audited-condensed-financial-statements-for-the-year-ended-31-december2020\%20(2).pdf. accessed 28 May 2021.

Albuquerque, A. L. \& Wiklund, C. H. (2015). Challenges to peace and security in Southern Africa: The role of SADC. Available 
at:http.//www.foi.se/download/18.2bc30cfb157f5e989c32897/1477655441380/Chal lenges+to+Peace+and+Security+in+Southern+Africa+The +of+SADC.Pdf. accessed 22 July 2020.

Creswell, J. (2009). Research design: qualitative and qualitative and mixed methods approaches $3^{\text {rd }}$ ed, Sage, Thousand Oaks. USA.

Deloitte (2020)"Hospitality sentiment survey(COVID-19) :Reopening and arriving at a new normal". available at https://www2.deloitte.com/mu/en/pages/life-sciencesand-healthcare/articles/hospitality-sentiment-survey-covid19.html. accessed 2 February 2021.

Deloitte (2021) "The future of the hospitality-uncovering opportunities to recover and thrive in the new normal". available at: https://www2.deloitte.com/content/dam/Deloitte/ca/Documents/consumerindustrial-products/ca-future-of-hospitality-pov-aoda-en.pdf. accessed 8 April 2021.

Dube, K. (2021) "Implications for COVID-19 induced lockdown on the .South African tourism industry and prospects for recovery":available at https://www.ajhtl.com/uploads/7/1/6/3/7163688/article_18_10_1_270-287.pdf. accessed 13 May 2021.

Falleiro, S. P. (2015). The economic and socio cultural balance sheet of tourism in Goa. International Journal of Scientific and Research Publication, 5(2): 2250-3153.

Gossling,S.;Scott,D. and Hall, C.M.(2020) Pandemics, tourism and global change, a rapid assessement of COVID -19: available at: https://www.tandfonline.com/doi/full/10.1080/09669582.2020.1758708. accessed 7 March 2021

Government of Zimbabwe: Ministry of Women's Affairs, Gender and Community Development (2011): Economic Empowerment of Women in the Tourism Sector.

Hlanyane T. M. \& Acheampong, O. K. (2017) Tourism entrepreneurship: the contours of challenges faced by female owned BnBs and Guest Houses in Mthata, South Africa. African Journal Hospitality, Tourism and Leisure, 6(4):1-17

Horaira, M. A. (2021) Impact of COVID-19 Pandemic on Tourism Industry: Possible Reconciliation Strategy for Bangladeshi Tourism Industry. International Tourism and Hospitality Journal, 4(4), pp. 1-17.

International Labour Organization: (2009) National profile of working conditions in the United Republic of Tanzania. available at: https://www.ilo.org/travail/info/publications/WCMS_119347/lang--en/index.htm. accessed 12 October 2020.

International Labour Organization (2020).C0VID-19 and the tourism sector . available at: https://www.ilo.org/sector/Resources/publications/WCMS_741468/lang-en/index.htm. Accessed 31 May 2021.

International Office of Migration (2016). South -South Mobility in Southern Africa. Available at: https://publications.iom.int/system/files/pdf/regional guide to facilitate southsouth_southern_africa.pdf. accessed 10 September 2020.

Jackson, H. (2002) UNAIDS 2000 report. New York, USA.

Johnston, M. P. (2014). Secondary data analysis a method for which the time has come. AST (3): 619-629. 
Lehloenya, P. M. (2017). Development and regulation of tourism for mutual benefits in Southern African Development Community (SADC). Available at: https://www.ajol.info/index.php/ldd/article/view/161038. Accessed 16 October 2020.

Lendeloo, S., Pinto, M.\& Sullivan, S. (2020) A perfect storm: The impact of COVID-19 on community based conservation in Namibia. Namibia Journal of Environment 2020(4). 1-15.

Southern African Development Community (SADC, 2020). SADC Today. 2(15): ISSN 2077-4907.

Makochekanwa, A. (2013). An analysis of tourism contribution to economic growth in SADC countries. Botswana Journal of Economics, 11(15) 42-56

Maseko, M.M.(2017) Effects of No-Compliance With the Occupational Health and Safety Act(no 85 of 1993) Among the Food and Beverages Industries in Selected Provinces of South Africa : $\mathrm{PhD}$ thesis (UP). available at: http://uir.unisa.ac.za/bitstream/handle/10500/21042/thesis_maseko_mm.pdf?sequen ce $=1 \&$ isAllowed $=y$. accessed 25 March 2020 .

Mbaiwa, J.E. (2008) "The Realities of Ecotourism Development in Botswana". in Spenceley, A.Ed. Responsible Tourism: Critical Issues for Conservation and Development. Earth scan Publishing. London, pp 205-223.

McCaston, M. K. (2005). Tips for collecting, reviewing and analysing secondary data. available at https://cyfar.org/sites/default/files/McCaston,\%202005.pdf. accessed 15 August 2020.

Motsatsi, M. ( 2018). Determinants of tourism demand in the SADC region. available at : https://media.africaportal.org/documents/determinants_of_tourism_demand_1.pdf. accessed 19 March 2021.

Mulder,N.(2020) The impact of COVID-19 pandemic on the tourism industry in Latin America and the Caribbean and options for sustainable recovery. available at https://www.cepal.org/en/publications/46502-impact-covid-19-pandemic-tourismsector-latin-america-and-caribbean-and-options. accessed 3 March 2020.

Nyaruwata, S. \& Nyaruwata, L.T.(2013). Gender Equity and Executive Management in Tourism: Challenges and Perspectives in Southern African Development Community (SADC) Region: African Journal of Business Management: 7(21) pp 2059-2070.

Nyaruwata, S. (2017). The Impact of Import Management Measures (SI64) on Tourism Businesses in Zimbabwe: Zimbabwe Tourism Business Council.

Nzama, T.A. (2010). Challenges of sustainable rural tourism in KwaZulu-Natal. Available at https://www.ajol.info/index.php/ijhss/article/view/62121. accessed 2July 2019.

Obasi, N. T. (2015). Tourism aesthetics and values. Journal of Tourism and Heritage Studies 4(1-2): 48-56.

OECD (2020) Rebuilding tourism for the future: COVID-19 policy responses and recovery. available at: https://www.oecd.org/coronavirus/policyresponses/rebuilding-tourism-for-the-future-covid-19-policy-responses-andrecovery-bced9859/. accessed 6 April 2021.

Page,J.(2021). Threat to jobs creation: tourism and COVID-19. available at : https://www.brookings.edu/blog/africa-in-focus/2021/02/18/threats-to-job-creationtourism-and-covid-19/. accessed 6 June 2021 
Ragoobur,V.T(2021) COVID-19 Islands Insites Services. Available at: http://islandstudies.com/files/2021/04/COVID19-Island-Insights-Series-09.-

Mauritius.-February-2021.pdf. accessed 6 June 2021.

Rogers, C.M. (2014). The uneven geography of tourism in South Africa. African Journal of Hospitality, Tourism and Leisure 3(1), 1-15

Rogers, C.M. (2012). The Tourism -Development Nexus in Sub-Sahara Africa: Progress and Prospect. Available at: https://www.ajol.info/index.php/ai/article/view/87651. Accessed 29 November 2020.

SADC (1998) Protocol on Tourism Development. www.sadc.int

SADC (2001) SADC Indicative Strategic Development Plan. www.sadc.int

Sheferahu, T.S. (2016). Challenges and prospectus of Ethiopian tourism industry. International Journal of Scientific \& Research Publications 6(6): 2250-3153.

Smith, E. (2008). Using secondary data in educational and social research. Open University Press, McGraw-Hill Education: Maidenhead. United Kingdom

Stone, L.S.; Mogomotsi,P.K. and Mogomotsi, G.(2021) The impacts of COVID-19 on nature based tourism in Botswana; implications for community development. Tourism Review International. 25,pp 263-278.

Taylor, R. (2009) "The Performance of CAMPFIRE in Zimbabwe 1989-2006" in Suich, H. and Child, B. with Spenceley, À. Ed. Evolution and Innovation in Wildlife Conservation. Earthscan Publishing. pp 201-222 London.

Tsangu, L. (2016) South African Tourism Graduates Perception of Decent Work in the Western Cape Tourism Industry: Master of Technology in Tourism dissertation. available at: http://etd.cput.ac.za/handle/20.500.11838/2670?mode=full. accessed 10 July 2019.

United Nations Conference on Trade and Development (2011) Tourism and Poverty Reduction, A Discussion Paper. available at: http://portal.unesco.org/en/files/48503/13045122901Tourism_Poverty_Reduction_ LDCs web.pdf/Tourism_Poverty_Reduction_LDCs_web.pdf.accessed 4 July $20 \overline{1}$

United Nations International Children's Education Fund (2018). The Cost Benefit Analysis of Tourism in Zanzibar. Available at: https://www.unicef.org/esa/sites/unicef.org.esa/files/2019-05/UNICEF-Tanzania2018-Cost-Benefit-Analysis-of-Tourism-in-Zanzibar.pdf. (accessed 6 June 2019)

United Nations Development Programme (2020).COVID-19 transforms tourism . available at: https://www.un.org/sites/un2.un.org/files/sg_policy_brief_covid19_tourism_august_2020.pdf. (accessed 2 February 2021)

United Nations Development Programme (2020). An Asssessement of socio-economic impact of COVID-19 IN Seychelles . available at: https://www.africa.undp.org/content/rba/en/home/library/reports/an-assessment-ofthe-socio-economic-impact-of-covid-19-in-seyche.html. (accessed 9 May 2021).

United Nations Development Programme (2021). Macroeconomic assessement of the impact of COVID-19 on tourism sector in Namibia and strategic recommendations for the recovery and revival of the sector. available at: http://theeis.com/elibrary/sites/default/files/downloads/literature/Namibia\%20Tourism\%20F inal\%20Report\%2020201217.pdf. ( accessed 15 April 2021).

United Nations World Tourism Organization (2020). Tourism Highlights 2019.avilable at: https://www.e-unwto.org/doi/book/10.18111/9789284421152 (accessed 8 June 2020) 
United Nations World Tourism Organization (2021). Tourism Highlights 2020. available at: https://www.e-unwto.org/doi/pdf/10.18111/9789284422456. (accessed 8 June 2021)

World Bank (2020). Tourism Industry Survey of South Africa:COVID-19 Impact, Mitigation and the Future Available at https://documents1.worldbank.org/curated/en/648261588959603840/pdf/TourismIndustry-Survey-of-South-Africa-COVID-19-Impact-Mitigation-and-the-FutureSurvey-1.pdf. (accessed 6 February 2021)

World Bank (2021). Banking on Protected Areas: Promoting Sustainable Protected Area Tourism to Benefit Local Economies. Available at: https://openknowledge.worldbank.org/handle/10986/35737?show=full. (accessed 15 June 2021)

World Economic Forum (2020). COVID-19 could set global tourism industry 20 years back . available at https://www.weforum.org/agenda/2020/09/pandemic-covid19tourism-sector-tourism/. (accessed 7 May 2021).

World Travel and Tourism Council (2020). Travel and Tourism Recovery Scenarios and Economic Impact from COVID-19. Available at: https://wttc.org/Portals/0/Documents/Reports/2020/Travel\%20Tourism\%20Recove ry $\% 20$ Scenarios $\% 202020 \% 20$ and $\% 20$ Economic $\% 20$ Impact $\% 20$ from $\% 20$ COVID19.pdf?ver=2021-02-25-183040-927. (accessed 7 April 2021.)

World Travel and Tourism Council (2020). To Recovery and Beyond: The Future of the Travel and Tourism Industry in the Wake OF COVID-19.available at: https://www.oliverwyman.com/content/dam/oliverwyman/v2/publications/2020/To_Recovery_and_BeyondThe_Future_of_Travel_and_Tourism_in_the_Wake_of_COVID-19.pdf. (accessed 8 February $202 \overline{1}$ ) 